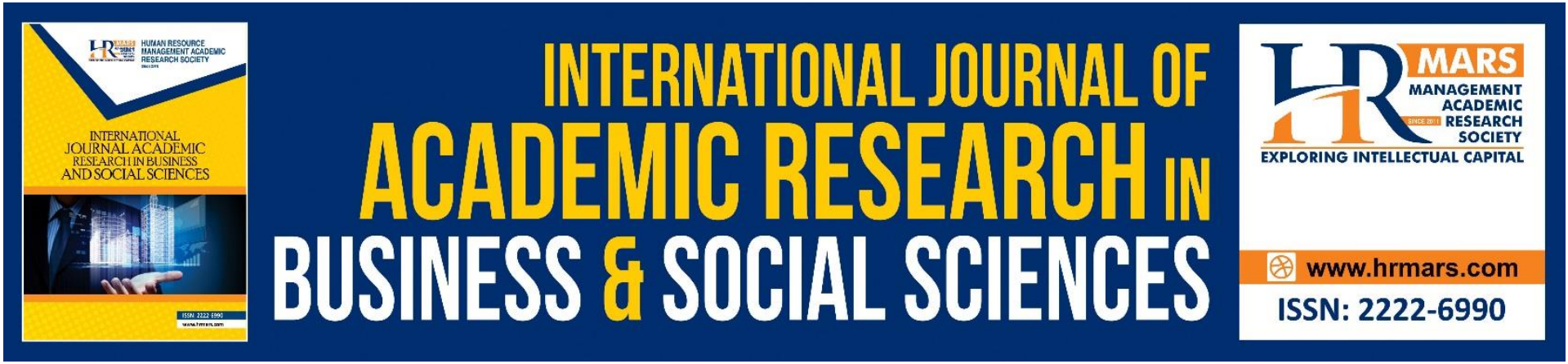

\title{
English Movies in a Malaysian English as a Second Language (ESL) Classroom Setting
}

\section{Zuriani Yaacob, Suriyati Ujang, Laily Zainal, Abdul Mutalib Embong}

To Link this Article: http://dx.doi.org/10.6007/IJARBSS/v11-i11/11521～DOI:10.6007/IJARBSS/v11-i11/11521

Received: 07 September 2021, Revised: 23 September 2021, Accepted: 16 October 2021

Published Online: 04 November 2021

In-Text Citation: (Yaacob et al., 2021)

To Cite this Article: Yaacob, Z., Ujang, S., Zainal, L., \& Embong, A. M. (2021). English Movies in a Malaysian English as a Second Language (ESL) Classroom Setting. International Journal of Academic Research in Business and Social Sciences, 11(11), 181-190.

\section{Copyright: (c) 2021 The Author(s)}

Published by Human Resource Management Academic Research Society (www.hrmars.com)

This article is published under the Creative Commons Attribution (CC BY 4.0) license. Anyone may reproduce, distribute, translate and create derivative works of this article (for both commercial and non-commercial purposes), subject to full attribution to the original publication and authors. The full terms of this license may be seen at: http://creativecommons.org/licences/by/4.0/legalcode

Vol. 11, No. 11, 2021, Pg. $181-190$

Full Terms \& Conditions of access and use can be found at http://hrmars.com/index.php/pages/detail/publication-ethics 


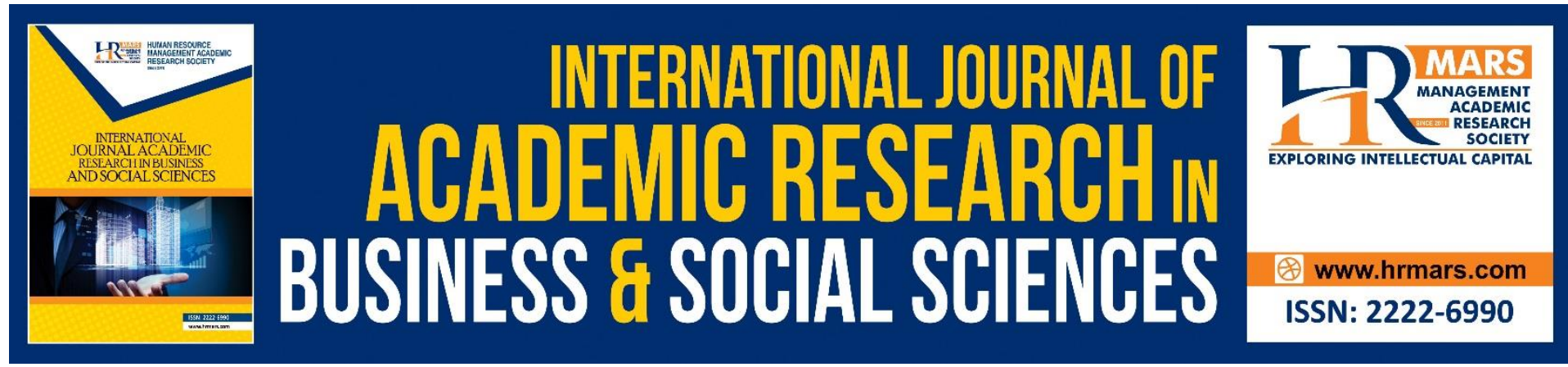

\title{
English Movies in a Malaysian English as a Second Language (ESL) Classroom Setting
}

\section{Zuriani Yaacob ${ }^{1}$, Suriyati Ujang², Laily Zainal ${ }^{3}$, Abdul Mutalib Embong ${ }^{4}$}

${ }^{1}$ Akademi Pengajian Bahasa, Universiti Teknologi MARA Pahang, Raub Campus, Pahang, ${ }^{2}$ Faculty of Computer and Mathematical Sciences, Universiti Teknologi MARA Pahang, Raub

Campus, Pahang, ${ }^{3}$ DRB Hicom University of Automotive Malaysia, Pekan Pahang,

${ }^{4}$ English Learning Centre, Centre for Foundation and Continuing Education (PPAL), Universiti Malaysia Terengganu (UMT)

Email: zurianibtyaacob@uitm.edu.my, suriyatiujang@uitm.edu.my, laily@dhu.edu.my, mutalib_embong@umt.edu.my

\begin{abstract}
Educators of second and foreign languages have paid close attention to the use of media specifically in English teaching and learning. The use of media includes watching movies, listening to music, watching films, and using other types of entertainment-related learning resources. The objective of this study is to investigate the effectiveness of English movies in second language learning acquisition. A quantitative research method was used to collect the data, with a questionnaire administered to 102 registered students of semester two and three from different non-English diploma programmes at Universiti Teknologi MARA (UiTM), Raub, Pahang. Based on the findings, language learners believe that movies are authentic sources of language learning and that they can be used effectively to improve their language skills such as speaking, listening and reading. Not only that, movies are also helpful for increasing student awareness of culture. More research is suggested to examine the types of movies on which language learners can rely in order to improve their language skills, compare groups learning English movies and control groups without movies using role-play activity, and assess the stress level of learning English through traditional classroom methods and watching movies. Hence, it would be understandable how movies can be used as educational tools in ESL classrooms.
\end{abstract}

Keywords: English, Movies, Malaysian, English as a Second Language (ESL), Classroom, Setting

\section{Introduction}

Language internationalisation is taking place around the world, and the English language has played a significant role in this transformation. As a result, many people around the world whose first language is not English have attempted to master the English language. It has been noted that one of the issues that contributes to students' poor language skills is limited exposure to English vocabularies (Wahyuningsih, 2018). It is true that without an adequate vocabulary, anyone would struggle to employ the four language abilities of listening, 
speaking, reading, and writing. In fact, different types of English materials have been used by second language instructors to determine the most appealing and effective method of learning the language (Cook, 2016). There is an expectation in English education that the teaching be varied and relevant to the learners' interests and daily lives.

In some places, learning a target language can be a complicated process that takes a lot of time and effort for language learners. ESL or EFL students have very limited exposure to the environment of natural language learning, so they face many challenges in learning English. However, according to Rao (2019), the incorporation of technology into the field of education has several advantages for both teachers and students in today's society. Due to the availability of cutting-edge technology, today's students are in a better position than previous generations. With the advent of modern technologies, learners may gain access to the content, acquire self-learning skills and become autonomous learners. Thus, English movies are better suited to them because they provide an experience in the real time of learning English. Young people today are fortunate to have a wide range of options for watching movies and TV shows, including traditional media such as television and cinema as well as streaming services such as Netflix and HBO. Movie's visuality makes it an invaluable language teaching tool, allowing learners to understand more by interpreting the language in its entirety (Yilmaz, 2020).

Movies aid learners' comprehension by allowing them to listen to language exchanges while also seeing visual supports such as facial expressions and gestures. These visual cues supplement the verbal message and serve as a focal point of attention. Another advantage of using movie is that it provides an authentic and varied source of language. Movies show students examples of English being used in 'real' situations outside of the classroom, particularly interactive language i.e. the language of real-life conversation. Students are exposed to natural expressions and the flow of speech through film. If they do not live in an English-speaking environment, perhaps only film and television can provide this real-world language input. One of the most important factors in determining successful second-language acquisition is motivation. Movie, as a motivator, also makes language learning more enjoyable and entertaining. Movies and television shows are an important part of students' lives, so incorporating them into the language classroom makes perfect sense. Ergo, it is worthwhile to investigate the effectiveness of English films as teaching and learning tools, as well as the advantages of watching English films to improve students' language skills.

\section{Literature Review}

Teachers of English used to use textbooks to teach the English language in traditional ESL or EFL classrooms, and students became bored with the monotonous teaching. Teachers in modern ESL or EFL classrooms use cutting-edge technology to capture the attention of their students. In this regard, English movies are more beneficial to English teachers in terms of adding a new dimension to the teaching and learning of English. Several studies on the effects of English movies on learning English in EFL or ESL classes have been undertaken by various researchers. The "vision" of English films is a valuable tool in this regard, Keddie (2014) states, which makes learners better learning by interpreting the language in a whole visual context. Gruba (2006) additionally adds that English films help students to understand by allowing them to listen to language exchanges and see such visual supports simultaneously, both as facial expressions and gestures. 
According to Kusumarasdyati (2004), English language teachers can also show English films with subtitles in their home language. Because of technological advancements, the number of people who watch English movies has grown. Subtitles may sometimes lead to new directions in language learning and understanding, and English language learners from various nations and cultures can appreciate these English movies. According to BirulésMuntané and Soto-Faraco (2016), subtitled English movies offer some potential benefits for students learning English or any other language. According to research on subtitled movies, using subtitled movies is more successful than non-subtitled movies at improving general listening comprehension. With the usage of subtitled movies in English classrooms, students gain the benefit of transitioning from a picture-viewing activity to a reading activity, which aids struggling readers by providing additional reading practise. It is fairly typical in EFL or ESL schools to show foreign language subtitles on the screen during viewings of English-spoken movies in general. On the other hand, the most recent DVD technology has the authoritative feature of selecting multiple subtitles, which may improve the listening comprehension of English language learners at various levels of competence and increase their drive to study the target language, i.e. English.

As the language of technology and globalisation, researchers from all over the world have conducted numerous studies on how to improve English in the English as a Second Language (ESL) classroom. Numerous teaching techniques and tools have been introduced and used in ESL classrooms to facilitate the learning process and improve students' communicative abilities in listening, speaking, reading, writing, vocabulary, and grammar. Using media is one of the tools that has been widely used in ESL classrooms. Media, in addition to making the learning process more enjoyable for students, also facilitates the teaching and learning process (Pitriana, 2013). Furthermore, watching English movies helps English language learners improve their language proficiency by providing them with a broader range of vocabulary, syntax, and other language skills (Khoshniyat \& Dowlatabadi, 2014).

Several researchers, including Ismaili (2013); Khoshniyat \& Dowlatabadi (2014); Li \& Wang (2015); Qiu (2017), argue that watching English movies to improve language competency has numerous advantages. It may not only improve students' oral and communication skills and motivate them, but it could also inculcate cultural awareness in an authentic language learning environment. In a study conducted by Ismaili (2013) among 6 EFL teachers and 60 EFL learners (aged 18 to 25) on the effect of using movies as teaching materials in English as a Foreign Language (EFL) classroom, it was discovered that using movies as teaching materials for three months increased student motivation and improved their language skills. Furthermore, teachers responded positively to the use of movies, believing that it could facilitate the learning process, improve the learning environment, and encourage student interaction, all of which could help students develop their language skills.

According to a similar study conducted by Kusumaningrum (2016) on the use and potential benefits of incorporating English movies into English as a Foreign Language classes in Indonesia, using English movies could facilitate the learning process and allow students to develop their speaking, writing, and listening skills in more engaging and interactive ways. The researcher also concluded that English movies do, in fact, provide more opportunities for language learners to teach and learn English in a natural learning environment. Qiu (2017) discovered that English movies are effective in improving listening skills among adult language 
learners after researching the effects of using English movies on the listening skills of college language learners. The researcher concluded that English films can provide significant educational benefits that make English learning and teaching more authentic and appealing to all language learners.

Similarly, Li and Wang (2015) investigated the impact of using English movies to improve the oral English skills of Chinese college students. After watching the movies, the students were assigned written and oral activities in which they had to summarise the plots. It has been discovered that students' oral skills, as well as their cultural awareness, have improved. According to the researchers, watching movies for educational purposes "enable students to learn the language in a real language environment and discover the cultural differences between Chinese and Western, then students' motivation can be aroused, and flexibility in real situations will be cultivated, thus enhancing the ability of foreign language communication and application" (Page 1100).

Albiladi, Abdeen, and Lincoln (2018) conducted a qualitative study with 25 adult language learners on their perceptions and opinions about using American movies to learn English and discovered that the participants had positive attitudes toward watching movies to learn English. The study concludes several benefits of using movies in English learning as identified by the research participants. The advantages include assisting language learners in developing skills such as speaking, listening, writing, vocabulary, and pronunciation. Furthermore, authentic learning materials increase their motivation to learn the language as well as their cultural awareness, which is critical for second language learners. According to a more recent qualitative study conducted by Fauzi et al (2021) among college students in Garut, West Java, the use of learning media, particularly movies, not only makes learning more interesting, but it also helps them learn new words and improve their vocabulary. Furthermore, when compared to writing and reading, listening and speaking are the most impactful skills because whatever they hear from native speakers can be used in a spoken form as they communicate.

Similarly, Emzir and Dewanti (2020) conducted an action research study with 30 college students at Darma Persada University over a year on using film as a media to improve speaking skills through collaborative learning. The findings revealed that using a movie as a medium caused student to become more active in the learning process of speaking skills, as evidenced by their level of participation in the learning interactions. The responses they gave to the lecturers, actively asking questions, paying attention to the movies, asking questions, and doing the assigned tasks all indicated an increase in their involvement. Students who previously struggled with speaking English found it easier to do so, and the lecture process became more enjoyable. Furthermore, the results of the three cycles of action obtained from the 30 students revealed an increase in the scores of the students' English-speaking skills tests. Finally, the review of the literature provided a positive insight into the benefits of using English movies in teaching and learning English among English as a Second Language learners.

\section{Methodology}

\section{Participants}

The participants in this study were the students taking English for academic purposes in current semester at Universiti Teknologi MARA (UiTM), Raub, Pahang. The study employed a convenience sampling method. There was no credit given if they agreed to answer the 
questionnaire. The ages of the participants ranged from 18 to 20 . Out of 102 total participants, approximately 27.5 percent are males and 72.5 percent are females.

\section{Instrument}

A quantitative research method was used to collect and analyze data for this research study where a self-administered questionnaire with two sections was used. Section A focused on the respondents' demographic backgrounds in terms of how long they have been studying English, how frequently they use English in daily life, and what skills related to English are frequently used. Section A also asked the participants how frequently they watched English movies and whether they used subtitles while watching. Besides, the participants were also asked to explain why they prefer to watch English films. Section B contains 21 Likert-scale questions on a scale of 1 to 5 , with 1 indicating strong agreement with the given statement and 5 indicating strong disagreement with the given statement. The questions in Section B range from whether watching English movies helped them improve their grammar, pronunciation, or appreciation for the movies alone.

\section{Results}

The participants were asked about their usage of English in their everyday lives. Only around 21.4 percent of them used English in everyday life, 45.9 percent barely once or twice a week, and the rest only three or four times a week. The participants were then asked if they utilised English on a regular basis and which skills they favoured. In this survey, the percentages for listening, reading, speaking, and writing are 43.3 percent, 21.1 percent, 30 percent, and 5.6 percent, respectively.

Table 1. Cross-Tabulation of the English Usage in Daily Life and the Skills Used

\begin{tabular}{lllllll}
\hline & & \multicolumn{2}{l}{ Skills } & & \\
\cline { 3 - 6 } & & Listening & Speaking & Reading & Writing & Total \\
\hline usage & $1-2$ times/week & 16 & 9 & 15 & 2 & 42 \\
& $3-4$ times/week & 15 & 5 & 7 & 3 & 30 \\
& Everyday & 7 & 4 & 5 & 0 & 16 \\
\hline Total & & 38 & 18 & 27 & 5 & 88 \\
\hline
\end{tabular}

According to the results in Table 1, 43.2 percent of the participants, who are undergraduate students, used their listening skills the most, while 30.6 percent read English articles the most. Only 4.54 percent of all participants used English in their daily lives. Meanwhile, writing is the least preferred skill, with only 5 participants admitting that they write, despite the fact that only 2 of them write once or twice a week, and the remaining 3 only write about 3 or 4 times a week.

The benefit of listening more among respondents may really help other language abilities such as reading and writing by showing them good English films. This is supported by Keddie (2014) that the "vision" of English films is a powerful tool that helps learners learn better by understanding the language in a larger visual context. Not only that, Gruba (2006) highlights that English films assist students learn by allowing them to listen to verbal exchanges while also seeing visual aids such as facial expressions and gestures. 
Table 2. Cross-tabulation of language preferred and subtitle use

\begin{tabular}{lllll}
\hline & & \multicolumn{2}{l}{ Preferred Language } & Total \\
\cline { 3 - 5 } & & Malay & English & 97 \\
\hline Subtitle & Yes & 16 & 81 & 5 \\
& No & 1 & 4 & 102 \\
\hline Total & 17 & 85 &
\end{tabular}

According to Table 2, roughly 95.1 percent of respondents preferred to watch English movies with subtitles. Furthermore, according to the cross-tabulation table, 79 percent utilised English subtitles, while the remaining 16 percent used Malay subtitles. Only 5\% of respondents indicated they did not use neither English nor Malay subtitles when watching movies. This is supported by Birulés-Muntané and Soto-Faraco (2016) in which subtitled English movies have the potential to help students studying English or any other language. They added that using subtitled movies improves general listening comprehension more than non-subtitled movies.

Further study was carried out to see if language skills and the frequency with which respondents watched English movies were connected using the Fischer Exact test, and it was revealed that there is no significant relationship between these variables.

Table 3. The frequency of respondents who believe that watching English films would help improve their language abilities.

\begin{tabular}{|ll|l|l|l|l|}
\hline \multirow{2}{*}{} & \multicolumn{2}{|l|}{ Frequency of watching English movies } & \\
\cline { 3 - 5 } & & Once a week & $3-5$ times/week & $\begin{array}{l}\text { Less than once a } \\
\text { week }\end{array}$ & Total \\
\hline Skill & Listening & 11 & 7 & 16 & 34 \\
& Speaking & 6 & 4 & 8 & 18 \\
& Reading & 12 & 6 & 8 & 26 \\
Total & 29 & 17 & 32 & 78 \\
\hline
\end{tabular}

Chi-Square Tests

\begin{tabular}{|l|l|l|l|}
\hline & Value & $\mathrm{df}$ & $\begin{array}{l}\text { Asymptotic } \\
\text { Significance } \\
\text { (2-sided) }\end{array}$ \\
\hline Pearson Chi-Square & $1.911^{\mathrm{a}}$ & 4 & .752 \\
Likelihood Ratio & 1.932 & 4 & .748 \\
Linear-by-Linear & 1.615 & 1 & .204 \\
Association & 78 & & \\
N of Valid Cases & & \\
\hline
\end{tabular}

According to Table 3, the majority of respondents believe that watching English movies will make language acquisition easier or will help them improve their English skills in general. Regardless of how frequently respondents watch English movies, approximately 44 percent believe it helps them improve their listening skills, followed by speaking and reading with 23 and 33 percent respectively. Finally, when asked why they watch English movies, 64.7 percent 
said it was because of the language, while 35.3 percent said it had nothing to do with language.

This is supported by Albiladi, Abdeen, and Lincoln (2018) who claimed that viewing English movies will help language learners acquire abilities such as speaking, listening, writing, vocabulary, and pronunciation. Furthermore, authentic learning materials improve their enthusiasm to study the language as well as their cultural awareness, both of which are important for second language learners.

\section{Conclusions and Recommendations}

According to the findings, the majority of students believed that including movies into their English language lessons might help them enhance their language abilities. According to the findings, the participants had favourable attitudes regarding viewing movies to learn English. The findings indicated that there seems to be consensus among the participating language learners regarding the efficacy of viewing movies. Significantly, the participants recognised a number of advantages associated with language acquisition. To begin, the findings of this study indicate that movies may be utilised successfully to enhance several language skills such as speaking, listening, vocabulary learning, and writing. The language learners who took part in the study were highly enthusiastic about the links between viewing movies and their language progress. In instance, virtually all of the participants who felt that movies were good sources for developing oral skills cited speaking and listening. If learners are exposed to more audio-visual technology, such as English movies, they will be able to quickly build the abilities required for second language acquisition and develop significantly in English language contexts. Considering English movies are more effective at increasing ESL or EFL learners' English language competence, English teachers must exercise caution when screening them in ESL or EFL classrooms. This is to ensure that the initiatives can be effectively maximised in order to produce meaningful teaching and learning.

Several academics have also stated that the type of movie that students watch influences their English learning abilities. Movies can be classified based on how they are presented; for example, films based on true events should be created for the purpose of communication. Documentary films, in particular, present the world's real events, regardless of when, where, or why they occur. Students, for example, will gain a better understanding of how the language might be used in real-life situations after watching this type of film. Certain types of movies, however, may be difficult to find, even if they are well-suited for use in an EFL classroom. This is because the movie the teacher is looking for isn't available on the internet, so the instructor should look for it elsewhere, such as a store that rents out movie cassettes.

Noting that the learners are capable of imitating what they would like to do, future research can be conducted to compare groups (groups learning through English movies, control groups without movies). To narrow the scope, the learning outcome for that specific lesson is based on performance during the role play activity implementation. In this case, a short clip from the selected English film that depicts the occurrence of real communication can be trimmed and tailored into the dialogue scripts before being distributed to all of the learners. Providing role-play dialogue based on topics of interest allows learners to engage in real-life communication while also developing fluency, which is an important aspect of speaking skill. Therefore, the experimental group will be exposed to the specific short clip performed by the 
actor or actress several times before being commanded to rehearse in groups for the role play activity. The same is true for the control group, in which the learners will also have their roleplay dialogue and the same amount of practise time will be provided before the role play activity begins. Data can be obtained to differentiate the performance of the experimental and control groups based on the assessment rubrics set by the teachers in regard to various aspects of speaking skill, such as pronunciation, intonation, and paralinguistic features associated with body language, gestures, facial expressions, tone, and pitch of voice.

Another study could be conducted to assess the level of stress associated with traditional classroom methods of learning English and watching movies. Students' involvement in the language classroom may result in increased stress level, particularly when they encounter unfamiliar grammatical structures, words, texts, and so forth. Without a doubt, watching movies is one of the leisure activities that should be done in order to create a stress-free atmosphere during the teaching and learning process. The difference between the experimental and control groups can be demonstrated by using a structured interview that revolves around the main question about the learners' general feelings about traditional classroom methods and watching movies. Aside from that, the researcher can elicit responses from respondents concerning the misconception of learning, which should be taken seriously and solemnly in nature rather than with laughter and hilarity.

In terms of future research, the findings of this study only provided insight into the attitudes of adult English language learners toward using movies to improve their language skills. The study did not provide answers to questions about the types of films that could be successfully used for educational purposes. As a result, more research is required specifically, research into the types of movies that adult language learners may use to improve their language skills. The researchers had a limited amount of time to complete the study due to the participants' tight schedules. In terms of future research, the current study did not investigate the relationship between students' positive attitudes toward using movies and their actual learning outcomes. There is much more research to be done on the relationship between learners' perspectives and beneficial learning outcomes.

Future studies should include more people from other groups, and the number of questionnaires distributed should be increased to support and confirm the findings. Due to the short time frame, this study relied solely on a questionnaire to collect data. Future research may conduct student interviews or administer a listening and speaking skills exam to gather additional information. Other intriguing research topics include determining whether English or Malay subtitles are more effective as learning media, as well as which movie genre is more beneficial in developing English abilities.

\section{References}

Albiladi, W. S., Abdeen, F. H., \& Lincoln, F. (2018). Learning English through movies: adult English language learners' perceptions. Theory and Practice in Language Studies, 8(12), 1567-1574.

Birulés-Muntané, J., Soto-Faraco, S. (2016) Watching subtitled films can help learning foreign languages. PLOS ONE 11(6).

Cook, V. (2016). Second language learning and language teaching. New York, NY: Routledge. Emzir, Y. N., \& Dewanti, R.D. (2020). Watching movie everyday can improve the foreign 
language speaking skill. International Journal of Multicultural and Multireligious Understanding, 7(8), 138-144.

Fauzi, W. R., Muljanto, S., \& Lestari, L. (2021). College students' perceptions on using movies for vocabulary learning. English Education and Applied Linguistics (EEAL) Journal, 4(1), 40-47.

Gruba, P. (2006). Playing the videotext: a media literacy perspective on video-mediated L2 listening. Language Learning and Technology, 10(2), 77-92.

Ismaili, M. (2013). The effectiveness of using movies in the EFL classroom-a study conducted at South East European University. Academic Journal of Interdisciplinary Studies, 2(4), 121-132.

McCarthy, M. J. (1990). Vocabulary. Oxford, UK: Oxford University Press. Press: Cambridge.

Kusumaningrum, M. (2016). Using English movie as an attractive strategy to teach senior high school students English as A foreign language. LLT Journal: A Journal on Language and Language Teaching, 18(1), 11-18.

Keddie, J. (2014). Bringing online video into the classroom. Oxford: Oxford University Press.

Khoshniyat, A. S., \& Dowlatabadi, H. R. (2014). Using conceptual metaphors manifested in Disney movies to teach English idiomatic expressions to young Iranian EFL learners. Procedia-Social and Behavioral Sciences, 98(1), 999-1008.

Kusumarasdyati. (2004). Listening, viewing and imagination: movies in EFL classes. 2nd International Conference on Imagination and Education Vancouver, Canada, July 14-17, 2004.

Li, X., \& Wang, P. (2015). A research on using English movies to improve Chinese college students' oral English. Theory and Practice in Language Studies, 5(5), 1096-1100.

Rao, P. S. (2019). The impact of English movies on learning English in ESL/EFL classrooms. Research Journal of English Language and Literature (RJELAL), 7(4), 430438.

Desi, P. J. (2013). The use of cartoon movie as a media in teaching vocabulary to young learners. Journal of English Language Teaching, 1(2), 106-113.

Qiu, J. (2017). The effect of English movies on college English listening teaching. Theory and Practice in Language Studies, 7(11), 1011-1024.

Wahyuningsih, S. (2018). Challenges and opportunities of teaching academic writing skills: a case study of students at IAIN Kudus. Jurnal Edulingua, 5(1), 15-24.

Yilmaz, F. (2020). Using films to teach Turkish as a foreign language: A study of classroom practice. Educational Research and Reviews, 15(6), 282-289. 